\title{
Moja przygoda z praktycyzmem
}

\author{
Juliusz Domański \\ (Warszawa, juldom@poczta.onet.pl)
}

Z Małego słownika języka polskiego pod redakcją Stanisława Skorupki, Haliny Auderskiej i Zofii Łempickiej z roku 1968 wynika, że abstrakcyjny rzeczownik „praktycyzm” do tamtego czasu nie zleksykalizował się w potocznej polszczyźnie, bo go w tym słowniku po prostu nie odnotowano, a z różnych aktualnych danych, jakie dziś można znaleźć m.in. w słownikach internetowych, widać, że nie wszedł on do zasobu leksykalnego potocznej polszczyzny i do teraz. W Słowniku wyrazów obcych i zwrotów obcojęzycznych Władysława Kopalińskiego, również z 1968 roku, „praktycyzm” pojawia się jako semantyczny derywat prakseologii, objaśniony formułami „ocena zjawisk i działań według ich użyteczności; niedocenianie znaczenia teorii w praktycznej działalności", a tym definicyjnym równowazinikom „praktycyzmu” towarzyszy objaśnienie etymologii i odsyłacz do hasła „pragmatyczny". Można więc przyjąć, że desygnat praktycyzmu znajduje się blisko takich pojęć, jak „skuteczność”, „pożytek”, „korzyść”. Kiedy dziesięć lat później, w roku 1978, na Mediävistentagung w Kolonii przedstawiłem opracowany po niemiecku referat z trochę nieprzyzwoicie długim tytułem Ethischer Praktizismus als eine Kategorie zum Beschreiben des Selbstbewusstseins der Philosophen im ausgehenden Mittelalter [Praktycyzm etyczny jako kategoria służąca opisowi świadomości filozoficznej u schyłku średniowiecza], to choć zacząłem go od zdefiniowania, co rozumiem pod terminem „praktycyzm etyczny”, zadano mi jednak w dyskusji pytanie (profesor Richard Heinzmann z monachijskiego Grabmanninstitut), dlaczego to, o czym mówię, nazwałem właśnie „praktycyzmem”. Domyślać się to pozwala, że i niemiecka świadomość językowa jako semantyczną dominantę słowa „Praktizismus” spontanicznie przywoływała wtedy treść podobną do tej, którą wyraził Kopaliński w swoim odsyłaczu.

Do dziś też w języku niemieckim tak mniej więcej pozostało. Internetowy słownik Dudena daje taką definicję: „Neigung, die praktische Arbeit zu verabsolutieren und dabei die theoretisch-ideologischen Grundlagen zu 
vernachlässigen"1, a inny jeszcze słownik internetowy notuje jako odcień znaczeniowy właściwy niemczyźnie dawnej NRD: „Neigung, in der Praxis aufzugehen und in Ideologie außer Acht zu lassen." ${ }^{2}$

Moją denominację wyjaśniłem w kolońskim wykładzie następująco:

Pod nazwą „praktycyzm etyczny” rozumiem pewien określony sposób pojmowania filozofii. Według tego sposobu filozofia nie jest tylko czystą wiedzą o rzeczywistości ostatecznej, lecz także pewnym szczególnym, etycznie określonym sposobem życia, który nie towarzyszy owej wiedzy niejako automatycznie, lecz musi być wypracowywany przez filozofów w staraniu i trudzie. Zakłada on konsekwentnie jedyne w swoim rodzaju cechy filozofa, nie tylko intelektualne, lecz także psychiczno-etyczne, względnie charakterologiczne, które razem tworzą „osobowość filozoficzną". Te dwie części składowe praktycystycznego pojęcia filozofii, a mianowicie theoria, która realizuje się jako wiedza o rzeczywistości ostatecznej, oraz praxis, urzeczywistniająca się w szczególnym etycznym zachowywaniu się filozofa, są od siebie nierozłączne i tworzą razem strukturę ustopniowaną, w której to, co etyczno-praktyczne, jest rozumiane najczęściej jako konsekwencja i ukoronowanie tego, co intelektualno-teoretyczne. Tam natomiast, gdzie bądź brakuje składnika etyczno-praktycystycznego, bądź nie da się stwierdzić strukturalnego związku między nim a tym, co intelektualno-teoretyczne, mamy do czynienia z czysto teoretycznym pojęciem filozofii jako samej tylko wiedzy (Domański 2008, 226-227)33.

\footnotetext{
${ }^{1} \mathrm{http}: / /$ www.duden.de/rechtschreibung/Praktizismus (dostęp: 7.04.2016)

2 Miło mi podziękować za wyszukanie tych informacji germaniście i poecie Jakubowi Ekierowi.

3 Cytuję w przekładzie Piotra Gwiazdeckiego, drukowanym w zbiorze moich prac drobniejszych Philosophica - paraphilosophica - metaphilosophica. Studia i szkice z dziejów myśli dawnej. W tamtejszej dokumentacji bibliograficznej powołałem się nie tylko na prace własne, gdzie został wielokrotnie użyty termin „praktycyzm”, ale i na cudze, zarówno te, które zawierały ten termin, jak i takie, które, nie posługując się nim, analogicznie do tamtych opisywały to samo pojęcie. Termin „praktycyzm” w odniesieniu do filozofii późnego średniowiecza był używany w polskiej literaturze z lat siedemdziesiątych ubiegłego wieku. Por. np. według indeksu pojęć s.v. „praktycyzm”. Co się tyczy eksplikacji samego pojęcia, ważnym świadectwem użycia go przez historyka filozofii średniowiecznej, i to (co tu szczególnie ważne, w związku z Etykq nikomchejskq Arystotelesa) jest także rozprawa J. Rebeta (1970). Próby metodycznego określenia pojęcia „praktycyzm” również poza obrębem
} 
Odpowiadając przed czterdziestu blisko laty na pytanie profesora Heinzmanna, odwołałem się do Arystotelesowego pojęcia i słowa praxis, którymi i teraz trzeba będzie się zająć dokładniej. Tymczasem dodam tylko, że terminem „praktycyzm” posługiwałem się od początku lat siedemdziesiątych, idąc w ślady innych polskich historyków filozofii dawnej. Niech tu za dokumentację obecności „praktycyzmu” w ich terminologii wystarczą dwie już wymienione książki: Stefana Swieżawskiego Dzieje filozofii europejskiej w XV wieku i Jerzego Rebety rzecz o komentarzu Pawła z Worczyna do Etyki nikomachejskiej Arystotelesa - obie z lat siedemdziesiątych ubiegłego wieku, gdzie obecność tego pojęcia i tego terminu świadczy o wcześniejszym już ich zadomowieniu się w pracach z dziejów myśli dawnej jako czymś w rodzaju wygodnego terminu technicznego, czyli pewnego typu skrótu myślowego, który funkcjonował mocą logiki konkretnych wywodów historycznofilozoficznych, nie bardzo licząc się z potocznym sensem słowa „praktycyzm” i pozostając też po dziś dzień bez wpływu na semantykę tego terminu nie tylko w języku potocznym, ale, zdaje się, także $\mathrm{w}$ języku filozofii, gdzie się pojawia raczej rzadko, a nawet, rzec można, tylko wyjątkowo ${ }^{4}$. Po pół wieku warto może poświęcić chwilę refleksji pytaniu, czy to skutek relatywnie małej popularności dziejów filozofii dawnej, w szczególności zaś średniowiecznej, czy może nieudatności samego terminu, jego drastycznej niekompatybilności z językiem potocznym.

Sens Arystotelesowej praxis, do którego się w kolońskiej dyskusji odwołałem, ujawnił mi się i utrwalił $\mathrm{w}$ świadomości dzięki moim pracom $\mathrm{z}$ wcześniejszych lat siedemdziesiątych - nie nad Arystotelesem samym, lecz nad średniowiecznymi polskimi komentatorami jego pism, a zwłaszcza Etyki

filozofii późnośredniowiecznej podjąłem się w pracach: Erazm i filozofia (1973), por. szczególnie 58-59; „Scholastyczne” $i$ „humanistyczne” pojęcie filozofii $(1978,2005)$. Bez posługiwania się terminem „praktycyzm”, lecz w odniesieniu do zjawisk bliskich temu, jakie ma opisać ten termin, późnostarożytne pojęcie filozofii przedstawione zostało przez następujących badaczy: H. von Arnim (1898), gdzie wyłożono rzecz we wprowadzeniu; A.-M. Malingrey (1961), a z nowszej literatury: J. Möller (1974) zwłaszcza s. 16; jednak szczególne znaczenie ma P. Hadot (1976), jego fundamentalna praca na temat autentycznego ducha filozofii starożytnej, otwierająca serię dalszych publikacji tegoż autora.

4 Żeby się ograniczyć do słowników (leksykonów) filozoficznych jako obrazu właśnie zleksykalizowania się terminu, odnotujmy po pierwsze obecność „praktycyzmu” w Słowniku terminów i pojęć filozoficznych Antoniego Podsiada (2000), gdzie znaczenie, o którym tu mowa, precyzyjnie zdefiniowane, znalazło się nawet na pierwszym miejscu, podczas gdy drugie przypadło znaczeniu bliskiemu tego, jakie podaje słownik Kopalińskiego, a po drugie, odnotujmy brak zupełny tego hasła w późniejszym o cztery lata Słowniku filozoficznym pod redakcją Adama Aduszkiewicza (2004). 
nikomachejskiej. Po dziesięciu mniej więcej latach od kolońskiej przygody napisałem i opublikowałem osobny artykuł o Arystotelesowym rozumieniu pojęć przygodności, zmienności i wolności, analizując z tej okazji również autoteliczność praxis, wynikającą z rozdziałów 1-6 szóstej księgi tego dzieła, wyraźną zwłaszcza wtedy, kiedy się ją zestawi z nieautotelicznością wytwarzania-tworzenia, nazywanego synonimicznym do pewnego stopnia słowem poiesis. Cytuję konkluzję:

[...] interpretacja uświadamia nam, na czym naprawdę polega autoteliczność etycznej praxis (na poziomie aktualizowania się cnót przybierającej nazwę energeia) w zestawieniu z heteroteliczną poiesis. Chodzi o to, że podczas gdy cel, a zarazem przedmiot działania wytwórczego, jest na zewnątrz zarówno tego działania, jak i działającego podmiotu, cel, a zarazem przedmiot działania etycznego, pozostaje $\mathrm{w}$ obrębie tego działania, a zatem również w obrębie działającego podmiotu (Domański 1986, 14).

Do tej konkluzji dołączam teraz rodzaj syntetyzującego dopowiedzenia tego, co zawiera się w cytowanym artykule w dość długiej i nieprostej analizie, mianowice dwie krótkie głosy takie oto:

(1) Najpierw ważny dla pojęcia Arystotelesowej zintrioryzowanej praxis początek księgi drugiej Etyki nikomachejskiej, rozróżnienie cnót noetycznych (intelektualnych) i cnót moralnych. Jest to proste a mocne stwierdzenie, że jeśli się dokonuje tego, co sprawiedliwe, roztropne, mężne, to sam dokonujący tego podmiot staje się sprawiedliwy, roztropny, mężny5.

(2) Po wtóre rozróżnienie między cnotą moralną a wytwórczością, obecne w różnych Arystotelesowych tekstach i formułowane na rozmaite sposoby, zawsze jednak sygnalizujące eksterioryzm działania wytwórczości, wychodzenie tego działania poza działający podmiot. Podczas gdy autoteliczna praxis jest samokształtowaniem się czy wręcz samotworzeniem się uprawiającego ją podmiotu, heteroteliczna poiesis ma za przedmiot tworzywo w stosunku do podmiotu zewnętrzne, a celem jest inny od podmiotu jej wytwór. Dystynkcja ta jest u samego Arystotelesa ledwie zaznaczana, a

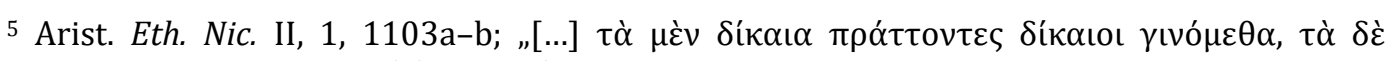

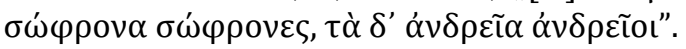


wyeksplikowali ją starannie, choć zdaje się oczywista, w taki właśnie sposób dopiero komentatorzy jego pism, szczególnie zaś pilnie średniowieczni scholastycy łacińscy. Podczas gdy skąpy, eliptyczny język samego Arystotelesa, określając cel i skutek praxis jako eupraxia, sugereuje niejako tylko jej samozwrotność, komentarze scholastyków łacińskich akcentują mocno podmiot praxis, nazywając ją po łacinie actio i agere, rzadziej operatio i operari, dla poiesis zaś rezerwując najczęściej factio i facere. Za przykład pierwszego niech tu wystarczy lakoniczna formuła Tomasza z Akwinu, że odrębna od factio i facere czynność wyrażana czasownikiem agere i jako pojęcie nosząca m.in. nazwę activa operatio „nie przechodzi na materię zewnętrzną i nie wytwarza przedmiotu, lecz pozostaje w działającym podmiocie"6.

Nie tylko jednak Arystoteles głosił taki interioryzm etycznego działania. Znała go dobrze już od samego swego początku tradycja sokratyczno-platońska, i głosiła na przkład jako zalecenie dbałości o duszę, w różnych zaś wariantach kontynuowały bliźniaczo podobny interioryzm doktryny filozoficzne z okresu hellenistycznego i rzymskiego. Do Arystotelesa warto było odwołać się tu przede wszystkim jako do uprawomocnienia ukutego terminu.

Zarazem jednak ograniczenie wyrażanego nim pojęcia do takiej interiorystycznej tylko treści budzi poczucie niedostatku nawet $\mathrm{w}$ odniesieniu do samego Arystotelesa. Jego etyka była etyką życia czynnego, ono zaś nie realizowało się inaczej niż w kontekście społecznym greckiej polis okresu klasycznego, tak samo zresztą jak i w myśleniu sokratejsko-platońskim, jak w ogóle w myśleniu greckim w epoce klasycznej. Niebezzasadnie wolno nawet zapytać, czy w ogóle była rdzennym składnikiem Arystotelesowego pojęcia filozofii. Może Arystotelesa trzeba uważać raczej za tego, który wyłączył filozofię i filozofów z owego społecznego kontekstu, mocno wyakcentowawszy jako dla nich swoisty odrębny rodzaj „życia teoretycznego”, poświęconego tylko badaniu i myśleniu, bios theoretikos, któremu nie była potrzebna

\footnotetext{
${ }^{6}$ S. Thomae Aquinatis Sententia Ethicorum (jak w przyp. 4), s. 338a: „[...] et haec est mens et ratio practica, quae quidem [...] principatur activae operationi quae non transit in exteriorem materiam sed manet in agente". Co do różnicy między actio/agere i factio/facere zob. np. Contra gentiles II. 1 (cytat, czy raczej jego słownikową parafrazę, powtarzam za Thomas Lexicon Schütza, pod hasłem „agere“: „prima igitur dictarum operationum (quae in ipso operante manet), tamquam simplex operantis perfectio, operationis vindicat sibi nomen vel etiam actionis, secunda vero (quae in exteriorem materiam transit) eo, quod sit perfectio facti, factionis nomen assumit" - zob. np.: http://www.corpusthomisticum.org/tl.html (dostęp: 7.04.2016).
} 
żadna odrębna praxis, bo jej autoteliczny efekt zawierał się już w pojęciu samotniczej theoria, i to tak dalece, że nawet nie wymagało to specjalnego wyjaśniania. I taki również aspekt zagadnienia etycznej praxis brałem pod uwagę w moich dawnych pracach metafilozoficznych, a dziś mi go daje widzieć jeszcze wyraźniej niedawno (i rzec można: przygodnie) lektura pewnej, dopiero co wydanej, cudzej książki .

A wreszcie, niezależnie już od sensu Arystotelesowej praxis jej idę̨ jako samotwórczości można i nawet trzeba rozpatrywać wychodząc od pojęcia osoby. I warto, uświadamiając sobie, że nie da się ona adekwatnie opisać, jeśliby ją traktować i w oderwaniu od współtworzących ją relacji międzyludzkich, i od rdzennie z nią związanej wytwórczości, tj. od poiesis. I o ten również kompleks zagadnień zdarzyło mi się kiedyś potrącić - trochę, ponownie, przygodnie i bez ścisłego związku z moimi historycznymi dociekaniami metafilozoficznymi (Domański 2009). A przecież od zupełnie innej strony musiał i w nich dać o sobie znać podobny problem, prowadzący do eksterioryzacji - by tak to nazwać - interiorystycznego, mianowicie na samotwórczości podmiotu etycznego, zbudowanego pojęcia praxis, która z tego tytułu miała być uzasadnieniem czy raczej usprawiedliwieniem, a do pewnego stopnia i podstawą pojęcia i nazwy „praktycyzm etyczny”. Wymagała tego próba opisania pojęcia filozofii w myśleniu humanistów i filozofów włoskiego quattrocenta, a w znacznej mierze także w myśleniu metafilozoficznym współczesnych im filozofów i (pre)humanistów polskich. Konfrontując w "Scholastycznym” i „humanistycznym” pojęciu filozofii ten sposób myślenia o człowieku - charakteryzujący z jednej strony takich myślicieli, jak Coluccio Salutati czy Giannozzo Manetti, którzy eksponowali w człowieku zarówno potrzeby poznawcze, jak i potrzebę tworzenia trwałych artefaktów w postaci bądź rozumnie zorganizowanych i rozumnie działających społeczności, bądź wytworów ludzkiej inwencji pojetycznej, czyli twórczoprzetwórczej, z drugiej zaś strony ideały takich interiorystów, jak Petrarka, Pico della Mirandola czy Erazm z Rotterdamu, na różne sposoby czyniących dominantą swego myślenia ideę etycznego samotworzenia się człowieka jako tworzącego z siebie samego jednostkowy podmiot etyczny - w Początkach humanizmu musiałem ostatecznie posłużyć się dwiema odmianami tej samej nazwy i tego samego pojęcia, rozdwoić je na „praktycyzm eksteriorystyczny” i „praktycyzm interiorystyczny” (Kuksewicz 1982, 21-25). 
Wracam na zakończenie, trochę ex abrupto, do spraw leksykalnych, od których zacząłem. Termin, starannie i aż do znudzenia od lat czterdziestu przeze mnie używany i wyjaśniany, nie przyjął się dotąd, nie wszedł do słownictwa nie tylko języka potocznego, ale nawet filozoficznego $\mathrm{w}$ tym znaczeniu, jakie mu zostało nadane. Jeżeli rzecz sama, którą próbowałem nim nazwać, na to zasługuje, to może warto poszukać innego, celniejszego i przez to łatwiejszego do oswojenia? Tom czasopisma, poświęcony interpretacji i recepcji filozofii antycznej, w tym między innymi zagadnieniu praktycyzmu, da może jakąś odpowiedź i na to pytanie.

\section{Literatura:}

Aduszkiewicz, A. (red.) 2004. Słownik filozoficzny, Warszawa: Świat Książki.

Arnim von, H. 1898. Leben und Werke des Dio von Prusa, Berlin: Weidmann.

Domański, J. 1973. Erazm i filozofia. Studium o koncepcji filozofii Erazma $z$ Rotterdamu. Wrocław: Zakład Narodowy im. Ossolińskich.

Domański, J. 1986. Przygodność, zmienność, wolność. Glosa do Etyki nikomachejskiej Arystotelsa, „Przegląd Tomistyczny” II, 5-18.

Domański, J. 2005. „Scholastyczne” $i$ „humanistyczne” pojęcie filozofii. Kęty: Antyk. (wyd. pierwsze: „Studia Mediewistyczne” XIX, z. l, 1978).

Domański J. 2008. Philosophica - paraphilosophica - metaphilosophica. Studia i szkice z dziejów myśli dawnej, Kraków: Polska Akademia Umiejętności (Rozprawy Wydziału Historyczno-Filozoficznego, ogólnego zbioru t. 109).

Domański, J. 2009. Trzy glosy do pojęć osoby i wspólnoty, „Acta Mediaevalia” XXII, 197-205.

Hadot, P. 1976. Exercices spirituels, „Ecole Pratique des Hautes Etudes, V-e Section Sciences Religieuses, Annuaire" 84, 25-70.

Kuksewicz, Z. (red.) 1982. Poczatki humanizmu. Wrocław: Ossolineum (= Dzieje filozofii średniowiecznej w Polsce, t. IX).

Malingrey, A.-M. 1961. „Philosophia”. Étude d'un groupe de mots dans la littérature grecque, des présocratiques au IV-e siècle après J.-C., Paris: Editions Klincksieck. 
Möller, J. 1974. Die moralische und politische Bedeutung der Philosophie, w: Möller, J. et Kohlenberger, H. Virtus politica. Festgabe zum 75. Geburtstag von Alfons Hufnagel, Stuttgart: Coron Verlag.

Podsiad, A. (red.) 2000. Słownik terminów i pojęć filozoficznych. Warszawa: Instytut Wydawniczy Pax.

Rebeta, J. 1970. Komentarz Pawła z Worczyna do „Etyki nikomachejskiej” Arystotelesa z 1424 roku. Zarys problematyki filozoficzno-społecznej, Wrocław: Ossolineum.

Swieżawski, S. 1974. Dzieje filozofii europejskiej $w$ XV wieku, t. 1-2, Warszawa: Akademia Teologii Katolickiej. 


\author{
Julisz Domański \\ (Warsaw, juldom@poczta.onet.pl) \\ My Adventure With Practicism
}

\begin{abstract}
For forty years I have been using in all my Polish scientific works the term "practicism" ("praktycyzm"), and its equivalents in my publications in French, German and Italian. This term has its strong background in Aristotle's notion and term of praxis, which was with precision defined in the commentaries to Nicomachean Ethics, in particular, by numerous medieval commentators. However, this term became not to be a popular one - both in colloquial and philosophical languages, although, it was used later by some other Polish historians of philosophy. When I relate today, and once again explain the sense of my studies on practicism, I do it to inspire young philosophers to search the new terms and definitions for better, maybe well-aimed, description of the phenomena and contents, which I called "practicism".
\end{abstract}

Keywords: practicism, Domskíi, praxis, Aristotle, ancient phiłophy, practical philosophy

Ethics in Progress (ISSN 2084-9257). Vol. 7 (2016). No. 2, Art. \#2, pp. 5-13.

Creative Commons BY-SA 3.0

Doi: 10.14746/eip.2016.2.2 